\title{
DETERMINAN GROWTH FAILURE (STUNTING) PADA ANAK UMUR 1 S/D 3 TAHUN (STUDI DI KECAMATAN TANJUNGKARANG BARAT KOTA BANDAR LAMPUNG)
}

\author{
Arie Nugroho \\ Jurusan Gizi Poltekkes Kemenkes Tanjungkarang \\ E-mail: arienugrohosgzmgz@gmail.com
}

\begin{abstract}
Determinants of the Growth Failure (Stunting) in Children around 1 to 3 years old who had Normal Birth Weight (A Study in west Tanjungkarang, Bandar Lampung). Stunting child is a child who has a height shorter than his age. Stunting indicates low growth and the cumulative effect of a lack of or insufficient intake of energy, macro nutrients or micro nutrients in the long term, or the result of chronic infections and infections that occur repeatedly. This study was to determine the factors associated with the Growth Failure (Stunting) in children aged 1-3 years who were born with normal weight in west Tanjungkarang, Bandar Lampung. This study was a case control research design. Subject of cases group were children who had growth failure (stunting), and controls group were children who had normal growth, total subject was 32 children in each group. The determinant variables that investigated were include length of birth, mother height, non-exclusive breastfeeding, complementary food feeding, allocation of parenting time, and socio-economics. Analysis was conducted by chi square and Odds Ratio. Based on results chi square, the determinants of growth failure (stunting) were: length of birth (OR=3,8 95\%CI: 1,11$12,98 ; \mathrm{p}=0,042)$, Non-exclusive breastfeeding ( $\mathrm{OR}=3,7 ; \quad 95 \% \mathrm{CI}: \quad 1,497-9,4 ; \quad \mathrm{p}=0,008)$, complementary food feeding (OR=3,7; 95\%CI: 1,497-9,4; $\mathrm{p}=0,008)$ and socio-economics $(\mathrm{OR}=3,4 ; 95 \% \mathrm{CI}: 1,17-9,80 ; \mathrm{p}=0,04)$. Mother height, allocation of parenting time were not the determinant factor. The main determinants of growth failure among child aged 1-3 years in west Tanjungkarang were length of birth, non-exclusive breastfeeding, complementary food feeding and socio-economics.
\end{abstract}

Keywords: Determinants of Stunting, Normal birth weight

\begin{abstract}
Abstrak: Determinan Growth Failure (Stunting) pada Anak Umur 1 s/d 3 Tahun (Studi di Kecamatan Tanjungkarang Barat Kota Bandar Lampung). Anak Stunting adalah anak yang memiliki tinggi badan lebih pendek dibandingkan dengan anak seusianya. Stunting mengindikasikan pertumbuhan yang rendah dan efek kumulatif dari kurangnya atau ketidakcukupan asupan energi, zat gizi makro atau zat gizi mikro dalam jangka panjang atau hasil dari infeksi kronis atau infeksi yang terjadi berulang kali. Penelitian ini bertujuan untuk mengetahui faktor-faktor yang berhubungan dengan Growth Failure (Stunting) pada anak umur 13 tahun yang lahir dengan berat badan normal di Kecamatan Tanjungkarang Barat Kota Bandar Lampung.Penelitian ini termasuk penelitian observasional dengan disain penelitian kasus-kontrol, yang dilakukan di Kecamatan Tanjungkarang Barat, Kota Bandar Lampung. Subjek yang dijadikan kasus adalah anak usia 1-3 tahun yang mengalami growth failure (Stunting), dan kontrol adalah anak 1-3 tahun yang mengalami pertumbuhan normal. Jumlah total subjek masing-masing kelompok kasus dan kontrol adalah 84 subjek. Variabel yang diamati meliputi panjang lahir, tinggi ibu, pemberian ASI yang tidak eksklusif, pemberian MP-ASI dini, alokasi waktu asuh, dan sosial ekonomi. Analisis data dilakukan dengan menggunakan uji chi squre dan menilai Odds Ratio (OR). Berdasarkan analisis chi squre, determinan Stunting adalah: Panjang lahir (OR=3,8 95\%CI: $1,11-12,98 ; p=0,042$ ) Pemberian ASI tidak eksklusif (OR=3,7; 95\%CI: 1,497-9,4; $p=0,008$ ), MPASI dini (OR=3,7; 95\%CI: 1,497-9,4; $p=0,008)$, dan Sosial Ekonomi (OR=3,4; 95\%CI:1,17-9,80; $p=0,04)$. Sedangkan variabel tinggi badan ibu dan alokasi waktu asuh bukan merupakan faktor determinan. Determinan growth faltering utama pada anak 1-3 tahun di Kecamatan Tanjungkarang barat adalah Panjang lahir, ASI tidak eksklusif, Pemberian MP ASI dini dan Sosial ekonomi. Disarankan untuk melakukan penyuluhan tentang pemberian ASI eksklusif dan MP-ASI dini serta peran serta Pemerintah daerah untuk meningkatkan status sosial ekonomi warganya.
\end{abstract}

Kata kunci: Determinan stunting, Berat lahir normal

Gangguan pertumbuhan merupakan awal kehidupan balita. Jika keadaan berlanjut kejadian yang sangat umum terjadi pada usia dapat menyebabkan gagal tumbuh (Growth 
Failure). Kegagalan pada pertumbuhan linear ditunjukkan dengan rendahnya tinggi badan dan nilai Z-Score menurut indeks TB/U dibandingkan dengan anak seusianya (Kemenkes RI, 2011).

Anak Stunting adalah anak yang memiliki tinggi badan lebih pendek dibandingkan dengan anak seusianya. Tinggi badan anak Stunting kurang dari -2SD berdasarkan indeks $\mathrm{TB} / \mathrm{U}$ menurut standar WHO 2005 (Taguri A.E et al, 2008, Kemenkes, 2011). Stunting mengindikasikan pertumbuhan yang rendah dan efek kumulatif dari kurangnya atau ketidakcukupan asupan energi, zat gizi makro atau zat gizi mikro dalam jangka panjang atau hasil dari infeksi kronis atau infeksi yang terjadi berulang kali (Allen L.H \& Gillespie SR, 2001).

Stunting merupakan keadaan kurang gizi menurut indeks tinggi badan menurut umur (TB/U) yang banyak terjadi pada anak balita terutama di negara-negara berkembang.

Growth faltering terjadi pada masa awal Faktor determinan yang dinilai sangat kuat pengaruhnya adalah infeksi dan gizi. Stunting merupakan indikator malnutrisi kronik yang menggambarkan riwayat kurang gizi dalam jangka waktu lama dan berkaitan dengan adanya proses perubahan patologis (Gibson R.S, 2005).

Stunting mengindikasikan masalah kesehatan masyarakat karena berhubungan dengan meningkatnya risiko morbiditas dan mempengaruhi kemampuan kognitif dan perkembangan anak (Allen L.H \& Gillespie SR, 2001, Santrock J.W, 2004). Stunting dipengaruhi oleh kekurangan asupan zat gizi makro dan mikro dalam jangka waktu yang lama, selain itu dipengaruhi oleh faktor lingkungan, sosial ekonomi dan intrauterine growth retardation (IUGR) (Monteiro C.A et al, 2010).

Kejadian Growth Failure pada tahun pertama kehidupan balita akan berdampak negatif terhadap pertumbuhan baik fisik maupun mental pada kehidupan balita selanjutnya (Walker et al, 2003). Ada berbagai macam faktor yang mempengaruhi Stunting. Penelitian yang dilakukan oleh Hayati dkk (2012) Semakin bertambah umur semakin meningkat prevalensi Stunting. Status Stunting berhubungan erat dengan umur, Risiko Stunting anak 6-11 bulan dan anak 12-23 bulan masing-masing 1.52 kali dan 2.04 kali dibanding anak 0-5 bln. Oleh karena itu penelitian ini dilakukan pada anak usia 1s/d 3 tahun. Selain itu faktor yang mempengaruhi Stunting adalah berat lahir, Risiko Stunting anak yg dilahirkan dg berat anak lahir rendah (BBLR) adalah 1.81 kali lebih tinggi dibanding anak lahir dg berat badan normal oleh karena itu penelitian ini dilaksanakan pada anak dengan berat badan lahir normal.

Pemilihan Kota Bandar Lampung menjadi lokasi penelitian karena kota Bandar Lampung memiliki prevalensi balita pendek $17,7 \%$ dan prevalensi untuk balita sangat pendek 13,9\% termasuk dalam 5 besar prevalensi tertinggi di Provinsi Lampung. Kecamatan Tanjungkarang Barat mempunyai prevalensi balita Stunting kedua tertinggi di Kota Bandar Lampung dibandingkan dengan Kecamatan lain yaitu 17,9\% balita pendek dan 19,7\% balita sangat pendek (Dinkes Kota Bandar Lampung, dalam Terati, 2013).

Tujuan penelitian ini adalah Diketahui faktor-faktor yang berhubungan dengan kejadian growth failure (Stunting) pada anak umur 1-3 Tahun yang lahir dengan berat badan normal di Kecamatan Tanjungkarang Barat Kota Bandar Lampung.

\section{METODE PENELITIAN}

Penelitian ini termasuk jenis penelitian analitik dengan disain penelitian kasus-kontrol, yang dilakukan di Kecamatan Tanjungkarang Barat, Kota Bandar Lampung. Subjek yang dijadikan kasus adalah anak yang mengalami growth failure (Stunting), dan kontrol adalah anak yang mengalami pertumbuhan normal. Jumlah subjek masing-masing kelompok kasus dan kontrol adalah 32 subjek. Pemilihan kontrol dilakukan dengan melakukan maching jenis kelamin dan umur.

Variabel yang diamati meliputi panjang lahir, tinggi badan ibu, ASI tidak eksklusif, MPASI dini, alokasi waktu asuh ibu dan sosial ekonomi.

Pengolahan data hasil penelitian yang telah dikumpulkan dilakukan menggunakan bantuan komputer. Analisis data menggunakan program komputer. Analisis dalam penelitian ini menggunakan uji chi square dan menilai Odds Rasio (OR).

\section{HASIL}

\section{A. ANALISIS UNIVARIAT}

Berdasarkan hasil penelitian umumnya responden memiliki Panjang Lahir normal yaitu sebanyak 68 subjek (81\%), Tinggi badan ibu umumnya normal yaitu 59 subjek $(70,2), 49$ subjek $(53,3 \%)$ tidak mendapatkan ASI ekslusif dan mendapatkan MP-ASI dini. Selain itu 59 subjek $(70,2 \%)$ diasuh oleh ibu lebih dari 16 jam 
dan sebagian besar orangtua responden yaitu 57 subjek $(67,9)$ memiliki pendapatan/ sosial ekonomi dibawah UMP (Upah Minimum Provinsi Lampung 2016) yaitu sebesar Rp.1.870.000 Selengkapnya dapat dilihat pada tabel 1 .

Tabel 1. Hasil Uji Univariat

\begin{tabular}{lcc}
\hline Karakteristik & Jumlah & \% \\
\hline Panjang Lahir & & \\
Pendek & 16 & 19,0 \\
$\quad$ Normal & 68 & 81,0 \\
Tinggi Badan Ibu & & \\
$\quad$ Pendek & 25 & 29,8 \\
$\quad$ Normal & 59 & 70,2 \\
ASI Ekslusif & & \\
$\quad$ Tidak ASI Ekslusif & 49 & 53,3 \\
$\quad$ ASI Ekslusif & 35 & 41,7 \\
MP- ASI dini & & \\
$\quad$ MP-ASI dini & 49 & 53,3 \\
$\quad$ MP- ASI tidak dini & 35 & 41,7 \\
Alokasi waktu asuh & & \\
$\quad$ Kurang dari 16 jam & 25 & 29,8 \\
$\quad$ Lebih dari 16 jam & 59 & 70,2 \\
Sosial ekonomi & & \\
$\quad$ < UMR & 57 & 67,9 \\
$\quad$ > UMR & 27 & 32,1 \\
\hline
\end{tabular}

\section{B. ANALISIS BIVARIAT}

\section{Panjang Lahir}

Secara umum subjek yang diteliti memiliki Panjang Lahir normal yaitu memiliki panjang badan $>46,1 \mathrm{~cm}$ untuk laki laki dan $>45,4$ untuk perempuan (KEMENKES, 2011) yaitu sebanyak 68 subjek (81\%), sedangkan sisanya 16 subjek memiliki panjang lahir pendek. Subjek yang mengalami Stunting dan memiliki panjang lahir pendek sebanyak 28,6\%, sedangkan subjek dengan panjang lahir pendek yang mengalami pertumbuhan normal sebanyak 9,5\%. Hubungan panjang lahir subjek dengan kejadian stunting dapat dilihat pada tabel 2 .

Tabel 2. Hubungan Panjang Lahir dengan Kejadian Stunting

\begin{tabular}{|c|c|c|c|c|c|c|}
\hline \multirow[t]{2}{*}{ Variabel } & \multicolumn{2}{|c|}{ Stunting } & \multicolumn{2}{|c|}{$\begin{array}{c}\text { Pertumbuhan } \\
\text { Normal }\end{array}$} & \multirow[t]{2}{*}{$\begin{array}{c}p \\
\text { value }\end{array}$} & \multirow{2}{*}{$\begin{array}{c}\text { CI } \\
95 \% \\
\text { OR } \\
\end{array}$} \\
\hline & $\mathbf{n}$ & $\%$ & $\mathbf{n}$ & $\%$ & & \\
\hline $\begin{array}{l}\text { Panjang } \\
\text { Lahir } \\
\text { Pendek }\end{array}$ & 12 & 28,6 & 4 & 9,5 & 0,042 & $\begin{array}{c}1,11- \\
12,98 \\
\text { (OR }\end{array}$ \\
\hline $\begin{array}{l}\text { Panjang } \\
\text { Lahir } \\
\text { Normal }\end{array}$ & 30 & 71,4 & 38 & 90,5 & & $=3,8)$ \\
\hline Jumlah & 42 & 100,0 & 42 & 100,0 & & \\
\hline
\end{tabular}

Hasil analisis hubungan antara panjang

lahir dengan stunting diperoleh bahwa ada sebanyak $12(28,6 \%)$ anak yang memiliki panjang lahir pendek mengalami Stunting, sedangkan anak yang memiliki panjang lahir normal yaitu sebanyak 30 anak (71,4\%) juga mengalami Stunting. Hasil uji statistik diperoleh $p$-value 0,042. Maka dapat disimpulkan ada hubungan yang signifikan antara panjang lahir anak dengan kejadian Stunting.

\section{b. Tinggi Badan Ibu}

Secara umum ibu subjek yang diteliti memiliki Tinggi badan normal, yaitu sebanyak 59 (70,2\%)orang dari 84 subjek, sedangkan sisanya $25(29,8 \%)$ ibu subjek pendek. Subjek yang mengalami Stunting dan memiliki ibu yang pendek sebanyak $15,6 \%$, sedangkan subjek yang mengalami pertumbuhan normal sebanyak $21,4 \%$. Hubungan antara tinggi badan ibu dengan kejadian stunting dapat dilihat pada tabel 3 .

Tabel 3. Hubungan Tinggi Badan Ibu dengan Kejadian Stunting

\begin{tabular}{lccccc}
\hline Variabel & \multicolumn{2}{c}{ Stunting } & \multicolumn{2}{c}{$\begin{array}{c}\text { Pertumbuhan } \\
\text { Normal }\end{array}$} & \multirow{2}{*}{$\begin{array}{c}\boldsymbol{p} \\
\text { value }\end{array}$} \\
\cline { 2 - 5 } & $\mathbf{n}$ & $\%$ & $\mathbf{n}$ & \% & \\
\hline $\begin{array}{l}\text { Tinggi } \\
\text { badan ibu } \\
\text { pendek }\end{array}$ & 16 & 38,1 & 9 & 21,4 & 0,152 \\
$\begin{array}{l}\text { Tinggi } \\
\text { badan ibu } \\
\text { normal }\end{array}$ & 26 & 61,9 & 33 & 78,6 & \\
\hline Jumlah & 42 & 100,0 & 42 & 100,0 & \\
\hline
\end{tabular}

Hasil analisis hubungan antara tinggi badan ibu dengan kejadian stunting diperoleh bahwa ada sebanyak $16(38,1 \%)$ anak yang memiliki ibu dengan tinggi badan pendek mengalami Stunting, sedangkan anak yang memiliki ibu dengan tinggi badan normal yaitu sebanyak 26 anak (61,9\%) juga mengalami Stunting. Hasil uji statistik diperoleh p-value 0,152 . Maka dapat disimpulkan tidak ada hubungan yang signifikan antara tinggi badan ibu dengan kejadian Stunting.

\section{c. Pemberian ASI Tidak Eksklusif}

Dari seluruh jumlah subjek, yang mendapatkan ASI tidak eksklusif sebanyak 40 anak $(53,3 \%)$. Hubungan pemberian ASI tidak eksklusif terhadap kejadian stunting dapat dilihat pada tabel tabel 4. Hasil analisis hubungan antara Pemberian ASI ekslusif dengan kejadian stunting diperoleh bahwa ada sebanyak $31(73,8 \%)$ anak yang tidak mendapat ASI ekslusif mengalami Stunting, sedangkan anak yang mendapat ASI ekslusif yaitu sebanyak 11 anak (26,2\%) juga mengalami Stunting. Hasil uji statistik diperoleh p-value 0,008. Maka dapat disimpulkan ada hubungan yang signifikan antara ASI ekslusif dengan kejadian Stunting. 
Tabel 4. Hubungan Pemberian ASI Tidak Eksklusif dan Kejadian Stunting

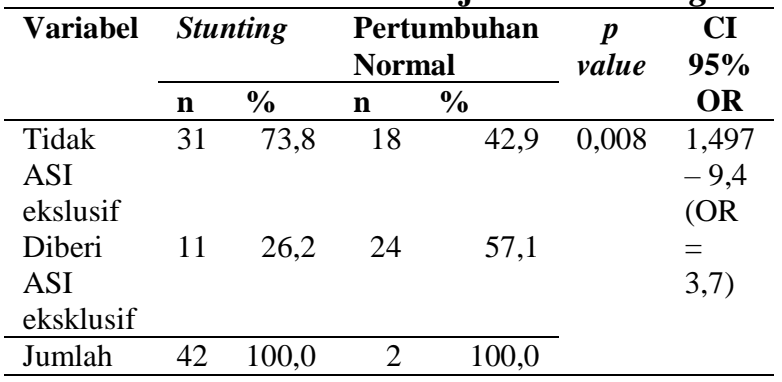

\section{d. Pemberian Makanan Pendamping ASI Dini}

Sebagian besar subjek diberi MP-ASI dini yaitu sebanyak 49 subjek $(53,3 \%)$. Sebagian besar subjek selain diberi susu formula juga masih disusui ASI oleh ibunya. Pemberian susu formula dilakukan dengan berbagai macam alasan diantaranya: ASI yang tidak keluar, atau tidak cukup untuk subjek, melanjutkan susu formula sejak dari Rumah Sakit atau bidan, dan alasan kepraktisan saat ditinggal pergi atau bekerja. Hubungan pemberian susu formula dan kejadian stunting dapat dilihat pada tabel 5. Hasil analisis hubungan antara MP ASI dini dengan kejadian stunting diperoleh bahwa ada sebanyak $31(73,8 \%)$ anak yang diberi MP-ASI dini mengalami Stunting, sedangkan anak yang tidak diberikan MP-ASI dini yaitu sebanyak 11 anak $(26,2 \%)$ juga mengalami Stunting. Hasil uji statistik diperoleh p-value 0,008. Maka dapat disimpulkan ada hubungan yang signifikan antara MP-ASI dini dengan kejadian Stunting.

Tabel 5. Hubungan MP ASI dini dan kejadian Stunting

\begin{tabular}{|c|c|c|c|c|c|c|}
\hline \multirow[t]{2}{*}{ Variabel } & \multicolumn{2}{|c|}{ Stunting } & \multicolumn{2}{|c|}{$\begin{array}{l}\text { Pertumbuhan } \\
\text { Normal }\end{array}$} & \multirow[t]{2}{*}{$\begin{array}{c}p \\
\text { Value }\end{array}$} & \multirow{2}{*}{$\begin{array}{c}\text { CI } \\
95 \% \\
\text { OR } \\
\end{array}$} \\
\hline & $n$ & $\%$ & $\mathbf{n}$ & $\%$ & & \\
\hline $\begin{array}{l}\text { MPASI } \\
\text { dini }\end{array}$ & 31 & 73,8 & 18 & 42,9 & 0,008 & $\begin{array}{l}1,497 \\
-9,4\end{array}$ \\
\hline $\begin{array}{l}\text { Tidak } \\
\text { MPASI } \\
\text { dini }\end{array}$ & 11 & 26,2 & 24 & 57,1 & & $\begin{array}{l}(\mathrm{OR} \\
= \\
3,7)\end{array}$ \\
\hline Jumlah & 42 & 100,0 & 42 & 100,0 & & \\
\hline
\end{tabular}

\section{e. Alokasi Waktu Asuh Ibu}

Sebagian besar subjek diasuh oleh ibunya lebih dari 16 jam perhari yaitu sebanyak 59 subjek $(70,2 \%)$. Hubungan alokasi waktu asuh ibu dan kejadian stunting dapat dilihat pada tabel 6.

Hasil analisis hubungan antara pola asuh dengan stunting diperoleh bahwa ada sebanyak $15(35,7 \%)$ anak yang mendapat alokasi waktu asuh kurang mengalami kejadian Stunting, sedangkan anak yang mengalami alokasi waktu baik yaitu sebanyak 27 anak (64,3\%) juga mengalami Stunting. Hasil uji statistik diperoleh $p$-value 0,34. Maka dapat disimpulkan tidak ada hubungan yang signifikan antara pola asuh dengan kejadian Stunting.

Tabel 6. Hubungan Pola Asuh dan Kejadian Stunting

\begin{tabular}{|c|c|c|c|c|c|}
\hline \multirow[t]{2}{*}{ Variabel } & \multicolumn{2}{|c|}{ Stunting } & \multicolumn{2}{|c|}{$\begin{array}{l}\text { Pertumbuhan } \\
\text { Normal }\end{array}$} & \multirow[t]{2}{*}{$\begin{array}{c}p \\
\text { value }\end{array}$} \\
\hline & $\mathbf{n}$ & $\%$ & $\mathbf{n}$ & $\%$ & \\
\hline $\begin{array}{l}\text { Alokasi } \\
\text { waktu }\end{array}$ & 15 & 35,7 & 10 & 23,8 & 0,34 \\
\hline $\begin{array}{l}\text { kurang } \\
\text { Alokasi } \\
\text { waktu } \\
\text { baik } \\
\end{array}$ & 27 & 64,3 & 32 & 76,2 & \\
\hline Jumlah & 42 & 100,0 & 42 & 100,0 & \\
\hline
\end{tabular}

\section{f. Sosial Ekonomi}

Pada saat penelitian sebagian besar orang tua subjek yaitu 57 subjek $(67,9 \%)$ memiliki tingkat sosial ekonomi rendah ditunjukan dengan penghasilan dibawah UMP Provinsi Lampung khususnya kota bandar lampung. Hubungan sosial ekonomi dan kejadian stunting dapat dilihat pada tabel 7. Hasil analisis hubungan antara sosial ekonomi dengan kejadian stunting diperoleh bahwa ada sebanyak 34 (81\%) anak yang orangtuanya memiliki sosial ekonomi kurang mengalami Stunting, sedangkan anak yang sosial ekonominya baik yaitu sebanyak 8 anak (19\%) juga mengalami Stunting. Hasil uji statistik diperoleh p-value 0,019. Maka dapat disimpulkan ada hubungan yang signifikan antara sosial ekonomi dengan kejadian Stunting.

Tabel 7. Hubungan Sosial Ekonomi dan Kejadian Stunting

\begin{tabular}{|c|c|c|c|c|c|c|}
\hline \multirow[t]{2}{*}{ Variabel } & \multicolumn{2}{|c|}{ Stunting } & \multicolumn{2}{|c|}{$\begin{array}{l}\text { Pertumbuhan } \\
\text { Normal }\end{array}$} & \multirow[t]{2}{*}{$\begin{array}{c}p \\
\text { value }\end{array}$} & \multirow{2}{*}{$\begin{array}{c}\text { CI } \\
95 \% \\
\text { OR }\end{array}$} \\
\hline & $\mathbf{n}$ & $\%$ & $\mathbf{n}$ & $\%$ & & \\
\hline $\begin{array}{l}\text { Sosial } \\
\text { ekonomi }\end{array}$ & 34 & 81,0 & 23 & 54,8 & 0,019 & $\begin{array}{l}1,31 \\
-\end{array}$ \\
\hline $\begin{array}{l}\text { kurang } \\
\text { Sosial } \\
\text { ekonomi } \\
\text { baik }\end{array}$ & 8 & 19,0 & 19 & 45,2 & & $\begin{array}{l}9,36 \\
\text { (OR } \\
= \\
3,51)\end{array}$ \\
\hline
\end{tabular}

\section{PEMBAHASAN}

\section{Panjang Lahir dengan Kejadian Stunting}

Pengaruh panjang lahir anak terhadap kejadian Stunting dianalisis dengan menggunakan uji chi squre. Hasilnya didapatkan $\mathrm{OR}=3,8$; 
95\%CI: 1,11-12,98; $p=0,042$. Dengan demikian dapat disimpulkan bahwa panjang lahir merupakan faktor risiko 3,8 kali terhadap kejadian Stunting.

Panjang badan lahir pendek merupakan salah satu faktor risiko stunting pada balita. Panjang badan lahir pendek bisa disebabkan oleh faktor genetik yaitu tinggi badan orang tua yang pendek, maupun karena kurangnya pemenuhan zat gizi pada masa kehamilan (Yupi, 2004).

Penelitian di Pati yang menunjukkan hasil bahwa panjang badan lahir merupakan faktor risiko kejadian stunting pada anak usia 12-36 bulan (Anugraheni HS, Kartasurya MI. 2012). Penelitian di Indramayu yang menunjukkan hasil bahwa anak yang lahir dengan panjang badan dibawah persentil -10 lebih berisiko tumbuh stunting. Bayi dengan panjang badan lahir pendek berpeluang lebih tinggi untuk tumbuh pendek dibanding anak panjang badan lahir normal (Kusharisupeni, 2002., Kusharisupeni. 2003).

Anak dengan panjang badan lahir pendek menunjukkan kurangnya gizi yang diasup Ibu selama masa kehamilan, sehingga pertumbuhan janin tidak optimal yang mengakibatkan bayi yang lahir memiliki panjang badan lahir yang rendah (Kusharisupeni, 2002). Faktor asupan dan penyakit memegang peranan yang menentukan apakah anak yang lahir dengan panjang badan lahir rendah akan tetap stunting selama masa hidupnya atau berhasil mencapai catch-up grow yang maksimal (Kiely JL et al, 2013) Anak yang lahir dengan panjang badan lahir pendek memang lebih berisiko untuk tumbuh stunting dibanding anak yang lahir dengan panjang badan normal, tetapi selama anak tersebut mendapatkan asupan yang memadai dan terjaga kesehatannya, maka kondisi panjang badan lahir yang pendek dapat dikejar dengan pertumbuhan seiring bertambahnya usia anak. Oleh karena itu kegiatan ANC perlu dilakukan secara rutin oleh ibu hamil terkait dengan panjang lahir yang berhubungan dengan kejadian stunting.

\section{Tinggi Badan Ibu dengan Kejadian Stunting}

Hubungan tinggi badan ibu terhadap kejadian Stunting dianalisis dengan menggunakan uji chi square. Hasilnya didapatkan $p=0,152$. Dengan demikian dapat disimpulkan bahwa tinggi badan ibu bukan merupakan faktor risiko terhadap kejadian Stunting.

Tinggi badan merupakan salah satu bentuk dari ekspresi genetik, dan merupakan faktor yang diturunkan kepada anak serta berkaitan dengan kejadian stunting. Anak dengan orang tua yang pendek, baik salah satu maupun keduanya, lebih berisiko untuk tumbuh pendek dibanding anak dengan orang tua yang tinggi badannya normal (Supariasa I.D.N dkk, 2002). Orang tua yang pendek karena gen dalam kromosom yang membawa sifat pendek kemungkinan besar akan menurunkan sifat pendek tersebut kepada anaknya. Tetapi bila sifat pendek orang tua disebabkan karena masalah nutrisi maupun patologis, maka sifat pendek tersebut tidak akan diturunkan kepada anaknya.

Terdapat hubungan yang positif dan signifikan antara tinggi badan ibu $<150 \mathrm{~cm}$ dengan stunting pada anak usia 0-23 bulan di Jawa Barat, Bali, dan NTT. Faktor risiko stunting anak usia 0-23 bulan di Bali, Jawa Barat, dan NTT adalah BBLR, tinggi badan ibu $<150 \mathrm{~cm}$, sanitasi kurang baik, dan pemberian makanan pre-lakteal (Nadiyah dkk, 2014).

Tinggi badan ibu yang pendek berisiko 1,3 kali memiliki balita stunting dibandingkan dengan dengan ibu yang memiliki tinggi badan yang tinggi Bila orang tua pendek akibat kekurangan zat gizi atau penyakit, kemungkinan anak dapat tumbuh dengan tinggi badan normal selama anak tidak terpapar faktor risiko lain (Dewey, K. G., \& Mayers, D.R. 2011).

Penelitian kohor yang dilakukan oleh Schmidt et al. (2002) di Jawa Barat menunjukkan bahwa pertumbuhan linear lebih ditentukan oleh lingkungan saat pra kelahiran daripada faktorfaktor pasca kelahiran. Lingkungan pra kelahiran yang dimaksud diantaranya adalah pertumbuhan saat masa janin yang indikatornya dapat dilihat dari berat badan saat lahir $(p=0.000)$. Kebanyakan BBLR disebabkan oleh faktor dari ibu, faktor terbesar yaitu anemia saat kehamilan (67\%). Faktor dari kehamilan sendiri, faktor paling besar adalah komplikasi saat kehamilan (22\%), sedangkan faktor lain yaitu genetik hanya sebesar 7\% (Asiyah et al. 2010).

Tinggi badan ibu kurang dari $150 \mathrm{~cm}$ menjadi faktor risiko stunting pada anak usia 023 bulan (OR=1.77; 95\%CI:1.20-2.59, $p<0.005)$. Menurut Kemenkes RI (2013), di Indonesia, prevalensi anak balita pendek dari kelompok ibu yang pendek $(<150 \mathrm{~cm})$ adalah $46.7 \%$, sedangkan prevalensi balita pendek dari kelompok ibu yang tinggi $(>150 \mathrm{~cm})$ adalah 34.8\%. Penelitian Schmidt et al. (2002) di Jawa Barat menyimpulkan bahwa setiap kenaikan $1 \mathrm{~cm}$ tinggi badan ibu, maka panjang badan bayi bertambah $0.196 \mathrm{~cm} \quad(p<0.000)$. Ini menjadi alasan penting anak perempuan menjadi target penting dalam perbaikan stunting hingga generasi selanjutnya. 
Banyak faktor yang mempengaruhi stunting, diantaranya adalah panjang badan lahir, status ekonomi keluarga, tingkat pendidikan dan tinggi badan orang tua. Panjang badan lahir pendek bisa disebabkan oleh faktor genetik yaitu tinggi badan orang tua yang pendek, maupun karena kurangnya pemenuhan zat gizi pada masa kehamilan (Yupi, 2004). Akan tetapi walaupun anak terlahir dari orangtua yang pendek tetapi selama anak tersebut mendapatkan asupan yang memadai dan terjaga kesehatannya, maka kondisi panjang badan lahir yang pendek dapat dikejar dengan pertumbuhan seiring bertambahnya usia anak (WHO, 2006).

\section{Pemberian ASI Tidak Eksklusif dengan Kejadian Stunting}

Pemberian ASI yang tidak eksklusif menjadi faktor risiko 3,70 kali terhadap kejadian Stunting.

Stunting dipengaruhi oleh riwayat pemberian ASI eksklusif dan penyakit infeksi, seperti diare dan Infeksi Saluran Pernafasan Akut (ISPA). Kebutuhan zat gizi pada usia 0-6 bulan dapat dipenuhi dari ASI. Anak yang tidak mendapatkan ASI eksklusif berisiko lebih tinggi untuk kekurangan zat gizi yang diperlukan untuk proses pertumbuhan. Begitu juga anak yang mengalami infeksi rentan terjadi status gizi kurang. Anak yang mengalami infeksi jika dibiarkan maka berisiko terjadi stunting. ASI eksklusif dapat menurunkan risiko kejadian stunting, karena kandungan kalsium pada ASI mempunyai bioavailabilitas yang tinggi sehingga dapat diserap dengan optimal terutama dalam fungsi pembentukan tulang anak (Horta BL et al, 2007., Susilowati et al, 2010).

Penelitian di Nepal tahun 2012 menyatakan pemberian ASI ekslusif berhubungan dengan kejadian stunting dimana anak yang tidak ASI ekslusif beresiko 6,9 kali menjadi stunting (Paudel R et al, 2012). Penelitian di Kota Palembang tahun 2013 menyatakan bahwa balita yang tidak mendapatkan ASI secara Eksklusif mempunyai peluang sebanyak 4.010 kali status gizi anak balitanya stunted dibandingkan ibu-ibu yang memberikan ASI-nya secara Eksklusif. Unicef (2013), menyebutkan bahwa memberikan ASI Eksklusif kepada anak selama 6 bulan pertama dapat meningkatkan pencapaian pertumbuhan, perkembangan dan kesehatan yang optimal. Setelah itu dapat dilanjutkan dengan memberikan makanan pendamping ASI sampai umur 2 tahun atau lebih. ASI merupakan sumber alami yang memiliki dampak yang besar pada kesehatan, pertumbuhan dan perkembangan anak
ASI berisi semua zat-zat gizi yang dibutuhkan oleh bayi dalam jumlah yang cukup. Kandungan energi ASI berkisar $65 \mathrm{mg} / 100 \mathrm{ml}$ ASI, adapun kandungan protein dalam ASI 0,9 $\mathrm{mg} / 100 \mathrm{ml}$ ASI. Kandungan protein dalam ASI memang lebih rendah dibandingkan dengan kadar protein susu formula $(1,6 \mathrm{mg} / 100 \mathrm{ml})$, namun kualitas protein ASI sangat tinggi dan mengandung asam-asam amino esensial yang sangat dibutuhkan oleh pencernaan bayi Keistimewaan protein ASI adalah rasio protein whey dan kasein yang seimbang (60 : 40), dibanding dengan susu sapi $(20: 80)$. Hal ini menguntungkan bayi karena pengendapan dari protein whey lebih halus dibanding kasein sehingga protein whey lebih mudah cerna (Lawrence, R \& Lawerence R.M, 2011). Jika bayi lapar atau haus, dia akan menyusu lebih sering atau lama, hal ini akan merangsang hormon prolaktin untuk memproduksi ASI lebih banyak, sehingga kebutuhan optimal bayi untuk pertumbuhan tercukupi (WHO, 2006).

\section{Pemberian Makanan Pendamping ASI Dini}

Hubungan pemberian MP- ASI dini terhadap kejadian Stunting dianalisis dengan menggunakan uji chi square. Hasilnya didapatkan OR=3,7; 95\%CI:01,497-94; $\mathrm{p}=0,008$. Dengan demikian dapat disimpulkan pemberian MP- ASI dini menjadi faktor risiko 3,70 kali terhadap kejadian Stunting.

Hasil ini sesuai dengan teori bahwa pemberian makanan pre-lakteal menjadi faktor risiko yang signifikan terhadap stunting pada anak $0-23$ bulan $(\mathrm{OR}=1.47, p<0.05)$. Penelitian menunjukkan anak yang menerima makanan prelakteal lebih berisiko stunting (OR=1.80; $p<0.05)$. Susu formula adalah jenis makanan prelakteal yang paling banyak ditemui dalam penelitian ini (53\%). Checkley et al (2008) menyatakan kejadian diare dan prevalensi diare lebih banyak terjadi pada bayi yang diberikan susu formula, hampir dua kali lipatnya dibandingkan bayi yang diberikan ASI. Pertumbuhan secara keseluruhan berhubungan negatif dengan jumlah kejadian diare. Anoreksia yang terjadi karena sakit lebih sering terjadi pada bayi yang diberikan susu formula.

Keluarga yang memberikan pola asuh baik terutama terhadap kebutuhan zat gizi, maka akan mempengaruhi status gizi anak. Pemberian MPASI yang tepat pada anak usia 12-24 bulan akan menurunkan risiko malnutrisi, karena pada usia tersebut kebutuhan zat gizi anak tidak dapat tercukupi hanya dari ASI saja (Anugraheni HS \& Kartasurya MI, 2012). 
MP-ASI berisi lebih banyak karbohidrat, dibanding ASI. Walaupun membuat kenyang, tapi tidak mengandung cukup zat-zat gizi yang dibutuhkan untuk pertumbuhan, terutama lemak dan protein, selain itu pemberian MP-ASI berkaitan dengan fungsi organ pencernaan. Semakin muda usia, maka organ pencernaan secara anatomis dan fisiologis belum berfungsi sempurna dan hanya dapat menampung dan mencerna sedikit makanan (Dewey, K. G., \& Mayers, D.R, 2011). Kecilnya daya cerna makanan, ditambah kandungan gizi yang tidak cukup, membuat bayi yang diberi MP-ASI pada usia yang lebih muda akan lebih rentan terhadap stunting.

Hasil penelitian di Kendari tahun 2016 menunjukkan bahwa proporsi balita stunting lebih banyak disebabkan oleh pemberian MP ASI pada usia $<6$ bulan di bandingkan pada balita yang tidak diberi MP ASI pada usia $<6$ bulan. Pemberian MP-ASI terlalu dini meningkatkan risiko penyakit infeksi seperti diare karena MPASI yang diberikan tidak sebersih dan mudah dicerna seperti ASI. Selain pemberian MP-ASI yang terlalu dini, terlambatnya memberikan MPASI juga menyebabkan pertumbuhan dan perkembangan balita menjadi terhambat karena kebutuhan gizi balita tidak tercukupi (Jihad dkk, 2016).

Penelitian ini sejalan dengan penelitian yang dilakukan kadek (2012) yang menyatakan balita yang diberi MP ASI terlalu dini berisiko 6,3 kali menjadi stunting di bandingkan balita yang diberi MP ASI tepat waktu.

Faktor risiko stunting anak usia 0-23 bulan di Bali, Jawa Barat, dan NTT adalah BBLR, tinggi badan ibu $<150 \mathrm{~cm}$, sanitasi kurang baik, dan pemberian makanan pre-lakteal (Nadiyah dkk, 2014).

\section{Alokasi Waktu Asuh Ibu}

Dalam penelitian ini pola asuh tidak berhubungan dengan kejadian stunting dikarenakan sebagian besar $59(70,2 \%)$ ibu memberikan alokasi waktu asuh $>16$ jam perhari untuk anaknya, hal ini karena sebagian besar responden $68(81 \%)$ adalah ibu rumah tangga yang dapat mencurahkan waktu penuh untuk anaknya. Penelitian menunjukkan bahwa alokasi waktu asuh ibu tidak berhubungan dengan pertumbuhan panjang badan anak. Hal yang lebih penting bukan lagi berapa lama ibu bersamasama dengan anaknya setiap hari, namun pada intensitas ibu dan anak sewaktu mereka sedang bersama-sama. Ibu bekerja diluar rumah, jarak antara rumah dengan tempat kerja dan banyak faktor lain semuanya akan mempengaruhi susunan makan dan pola asuh terhadap anaknya. Sehingga ibu yang tidak bekerja akan mempunyai waktu yang lebih banyak dengan anaknya dan mempengaruhi peningkatan kualitas gizi anaknya (Sulastri, 2012).

Stunting merupakan gangguan pertumbuhan linier yang diunjukkan dengan tinggi badan menurut umur <-2 standar deviasi dari median tinggi badan menurut umur berdasarkan standar populasi yang dijadikan referensi. Stunting pada anak usia 2 tahun berawal dari ibu hamil kurang gizi. Stunting juga disebabkan praktik pemberian makan yang buruk, kualitas makanan tidak baik, serta infeksi. Selain itu, pelayanan kesehatan yang optimal, akses terhadap air bersih, dan sanitasi juga berpengaruh. Secara umum penyebab utama stunting adalah retardasi pertumbuhan intrauteri, asupan gizi yang tidak mencukupi, dan penyakit infeksi selama awal kehidupan terkait dengan pola asuh ibu (Black et al, 2013).

Penelitian di Nepal tahun 2012 menyatakan pola asuh oleh ibu berhubungan dengan kejadian stunting dimana anak yang tidak diasuh oleh ibu dan atau waktu asuh kurang beresiko 3,02 kali menjadi stunting (Paudel R et al, 2012).

\section{Sosial Ekonomi}

Pengaruh sosial ekonomi terhadap kejadian Stunting dianalisis dengan menggunakan uji chi square. Hasilnya didapatkan nilai $\mathrm{OR}=3,51$; 95\%CI: $1,31-9,36 ; p=0,019$. Dengan demikian dapat disimpulkan Sosial ekonomi orangtua akan meningkatkan resiko kejadian Stunting sebanyak 3,51 kali dibanding subjek yang sosial ekonomi baik.

Terdapat hubungan yang signifikan antara pendapatan keluarga dengan stunting pada anak $(p<0.05)$. Terdapat hubungan yang positif dan signifikan antara pendapatan rendah dengan stunting pada anak usia 0-23 bulan di Jawa Barat, Bali, dan NTT (Nadiyah dkk, 2014).

Berdasarkan banyak penelitian, status ekonomi lebih banyak berpengaruh terhadap pertumbuhan linear dibandingkan pertumbuhan berat badan. Hubungan status ekonomi dan stunting juga ditemukan dalam penelitian Girma dan Genebo (2002) di Ethiopia terhadap 9768 balita. Penelitian tersebut menunjukkan risiko stunting paling tinggi pada anak dari golongan status ekonomi paling miskin $(\mathrm{OR}=2.01)$, sedangkan anak dengan status ekonomi miskin berpeluang stunting 1.87 kali. Kedua OR diatas dibandingkan dengan anak golongan ekonomi 
menengah/ke atas.

Status ekonomi keluarga akan mempengaruhi kemampuan pemenuhan gizi keluarga maupun kemampuan mendapatkan layanan kesehatan. Anak pada keluarga dengan tingkat ekonomi rendah lebih berisiko mengalami stunting karena kemampuan pemenuhan gizi yang rendah, meningkatkan risiko terjadinya malnutrisi (Fernald LC, Neufeld LM, 2007).

Berdasarkan penelitian di kota palembang tahun 2013 sebagian besar anak stunting memiliki status sosek keluarga <UMR sebesar $51.6 \%$, dan diperoleh hubungan antara status sosial ekonomi keluarga dengan kejadian stunting. Semba et al (2008) yang menyebutkan bahwa di Indonesia prevalensi stunted berdasarkan pengeluaran perkapita berkisar antara $30.9 \%$ sampai $37.6 \%$, dimana prevalensi tertinggi pada kuintil I dan terendah pada kuintil 5. Stunted berhubungan dengan rendahnya pengeluaran perkapita keluarga. Penelitian di Nepal tahun 2012 menyatakan sosial ekonomi keluarga berhubungan dengan kejadian stunting dimana anak dengan sosial ekonomi menengah kebawah beresiko 3,11 kali menjadi stunting (Paudel R et al, 2012). Faktor risiko kejadian stunting pada anak usia 12-24 bulan di Kecamatan Semarang Timur adalah status ekonomi keluarga rendah $(\mathrm{OR}=11.769)$ (Husein Al-Anshori \& Nuryanto.2013). Status sosial ekonomi dipengaruhi pendidikan seseorang, yang akan berpengaruh terhadap peluang mendapatkan pekerjaan. Pekerjaan akan berpengaruh terhadap status ekonomi keluarga. Penelitian di Maluku pada anak usia 0-23 bulan dan penelitian di Bogor pada anak usia 6-12 bulan menunjukkan ada hubungan pendapatan keluarga dengan kejadian stunting (Anugraheni HS, Kartasurya MI, 2012., Ramli et al, 2009).

Keluarga dengan status ekonomi rendah akan mempunyai kesempatan untuk mencukupi kebutuhan pangan dan gizi keluarga yang rendah, sehingga anak lebih rentan terjadi stunting. Keluarga dengan status ekonomi tinggi memiliki kesempatan untuk memilih bahan makanan yang lebih bervariatif serta kebutuhan zat gizi tercukupi, sehingga risiko kejadian masalah gizi dapat ditekan. Hasil ini sesuai dengan penelitian di Maluku, bahwa keluarga dengan status ekonomi rendah merupakan faktor risiko kejadian stunting (Anugraheni HS \& Kartasurya MI, 2012).

Sosial ekonomi berhubungan erat dengan ketersediaan pangan keluarga, dimana ketersediaan pangan yang rendah mampu meningkatkan risiko 3,64 kali lebih besar untuk menghasilkan anak yang stunting dibandingkan dengan ketersediaan pangan keluarga yang baik. Rendahnya ketersediaan pangan, mengancam penurunan konsumsi makanan yang beragam dan bergizi seimbang dan aman di tingkat rumah tangga. Pada akhirnya, akan berdampak pada semakin beratnya masalah gizi masyarakat, termasuk stunting pada batita. Masalah akses dan ketersediaan pangan untuk penduduk miskin merupakan gabungan dari masalah kemiskinan, kurangnya pekerjaan tetap, pendapatan tunai rendah dan tidak tetap serta terbatasnya daya beli (BAPENAS, 2011).

Status ekonomi keluarga yang rendah akan mempengaruhi kualitas maupun kuantitas bahan makanan yang dikonsumsi oleh keluarga. Makanan yang didapat biasanya akan kurang bervariasi dan sedikit jumlahnya terutama pada bahan pangan yang berfungsi untuk pertumbuhan anak seperti sumber protein, vitamin dan mineral, sehingga meningkatkan risiko kurang gizi. Keterbatasan ini akan meningkatkan risiko terjadinya stunting pada anak balita (Astari LD dkk, 2005).

Berdasarkan hasil penelitian ini sosial ekonomi berhubungan dengan kejadian stunting sehingga perlu peran serta pemerintah daerah dalam peningkatan status sosial ekonomi yang berhubungan dengan kejadian stunting pada anak usia 1-3 tahun.

\section{SIMPULAN}

Hasil penelitian menunjukkan bahwa determinan stunting adalah: Panjang lahir (OR= 3,8 95\%CI: 1,11-12,98; $p=0,042)$ Pemberian ASI tidak eksklusif (OR=3,7; 95\%CI: 1,497-9,4; $\mathrm{p}=0,008)$, MP-ASI dini (OR=3,7; 95\%CI: 1,497 - 9,4; $p=0,008)$, dan Sosial Ekonomi ( $\mathrm{OR}=3,4$; 95\% CI:1,17-9,80; $p=0,04)$. Sedangkan variabel tinggi badan ibu dan alokasi waktu asuh bukan merupakan faktor determinan.

\section{SARAN}

Perlu ditingkatkan promosi pentingnya kegiatan ANC, pemberian ASI eksklusif dan MP ASI dini, oleh Bidan Desa di Kecamatan Tanjungkarang Barat melalui penyuluhan sejak pemeriksaan kehamilan untuk mencegah kejadian Stunting pada anak usia 1- 3 tahun. Serta perlu peran serta pemerintah daerah dalam peningkatan status sosial ekonomi yang berhubungan dengan kejadian stunting pada anak usia 1-3 tahun. 


\section{DAFTAR PUSTAKA}

Allen L.H, Gillespie SR. 2001. What Works? A Review of The Efficacy and Effectiveness of Nutrition Interventions. Manila. ADB.

Anugraheni HS, Kartasurya MI. 2012. Faktor risiko kejadian stunting pada anak usia 12-36 bulan di Kecamatan Pati, Kabupaten Pati. Eprints Undip.

Asiyah S, Suwoyo, \& Mahaendriningtyastuti. 2010. Karakteristik bayi berat lahir rendah sampai tribulan II Tahun 2009 di Kota Kediri. Jurnal Kesehatan Suara Forikes, 1(3), 210-222.

Astari LD, Nasoetion A, Dwiriani CM. 2005. Hubungan Karakteristik Keluarga, Pola Pengasuhan dan Kejadian Stunting Anak Usia 6-12 Bulan. Media Gizi dan Keluarga, 29 (2): 40-46.

Badan Perencanaan Pembangunan Nasional. 2011. Rencana Aksi Nasional Pangan dan Gizi 2011-2015. Jakarta: Bappenas.

Black R, Victora C, Walker S, Bhutta Z, Christian $\mathrm{P}$, de Onis M, et al. 2013. Maternal and child undernutrition and overweight in low-income and middle-income countries. Lancet, 382(9890):427-51.

Checkley , Buckley G, Gilman RH, Assis AM, Guerrant RL, Morris SS, Mølbak K, Valentiner-Branth P, Lanata CF, Black RE. 2008. Multi-country analysis of the effects of diarrhoea on childhood stunting. http://www.ncbi.nlm.nih.gov/pubmed/1856 $\underline{7626}$

Dewey, K. G., \& Mayers, D.R. 2011. Early Child Growt : How Do Nutrition and Infection Interact?. Maternal and Child Nutrition, volume 7 issue supplement s3.

Fernald LC, Neufeld LM. 2007. Overweight With Concurrent Stunting In Very Young Children From Rural Mexico: Prevalence And Associated Factors. European Journal of Clinical Nutrition.

Gibson. R.S. 2005. Principles of Nutritional Assessment. 2nd ed. New York: Oxford University.

Girma W \& Genebo T. 2002. Determinants of the Nutritional Status of Mothers and Children in Ethiopia. ORC Macro, Calverton, Maryland, USA.

Hayati A.W, Hardinsyah, Jalal F, Madanijah S, Briawan D. 2012. Determinan Stunting Anak Baduta. Makalah disampaikan di: Widyakarya Nasional Pangan Dan Gizi X Jakarta. 20 Nopember 2012.

Horta BL, Bahl R, Martines JC, Victoria CG. 2007. Evidence on the long-term effects of breastfeeding. Geneva, Switzerland. World Health Organization.

Husein Al-Anshori \& Nuryanto. 2013. Faktor Risiko Kejadian Stunting Pada Anak Usia 12-24 Bulan (Studi Di Kecamatan Semarang Timur). Eprints Undip.

Jihad, Janirah., Ode Ali Imran Ahmad, Ainurafiq. 2016. Analisis determinan kejadian stunting pada balita usia 12-24 bulan Di wilayah kerja puskesmas puuwatu kota kendari tahun 2016. Fakultas Kesehatan Masyarakat Universitas Halu Oleo.

Kiely JL, Yu S, Rowley DL. 2013. Low Birth weight and intrauterine growth retardation. CDC public health surveillance for women, infants and children. http://www.cdc.gov/ (Diakses pada 12 Maret 2013)

Kemenkes. 2011. SK Menkes 2010 tentang Standar Antropometri Penilaian Status Gizi Anak. Direktorat Jenderal Bina Gizi dan Kesehatan Ibu dan Anak. Direktorat Bina Gizi.

Kusharisupeni. 2002. Growth Faltering pada Bayi di Kabupaten Indramayu Jawa Barat. Makara, Kesehatan, vol. 6, no. 1, juni 2002.

Kusharisupeni. 2003. Peran Status Kelahiran terhadap Stunting pada Bayi: Sebuah Studi Prospektif. J Kedokter Trisakti. Vol.23 No.3.

Lawrence, R \& Lawerence R.M 2011. Breastfeeding A Guide For The Medical Profession, $7^{\text {th }}$ Ed, Elsevier Health Sciences, USA.

Monteiro C.A, Helena M, Conde W.L, Konno S, Lovadino A.L, Barros A.J.D, Victora C.G. 2010. Narrowing socioeconomic inequality in child stunting: the Brazilian experience 1974-2007. Bull World Health Organ 2010; 88:305-311.

Nadiyah, Dodik Briawan, dan Drajat Martianto. 2014. Faktor Risiko Stunting pada Anak Usia 0-23 Bulan di Provinsi Bali, Jawa Barat, dan Nusa Tenggara Timur . Jurnal Gizi dan Pangan, Juli 2014, 9(2): 125-132.

Paudel R, Pradhan B, Wagle RR, Pahari DP, Onta SR. 2012. Risk Factors for Stunting Among Children: A Community Based Case Control Study in Nepal. Kathmandu University Medical Journal,Vol.1, No. 3, Issue 39, Jul- Sep 2012.

Ramli, Agho KE, Inder KJ, Bowe SJ, Jacobs J, Dibley MJ. 2009. Prevalence and Risk Factors for Stunting and Severe Stunting 
Among Under-Five in North Maluku Province of Indonesia. BioMed Central. 2009: 1-10.

Santrock J.W. Child Development. Ed.10 McGraw-Hill Higher Education. 2004.

Semba RD de Pee, Sun Kai, Sari M, Akhter N, Bloem MW. 2008. Effect Of Parental Formal Education on Risk of Child Stunting in Indonesia and Bangladesh a Cross Sectional Study, lancet: 371: 322-28.

Schmidt, Marjanka, Siti Muslimatun, Clive E.West, Werner Schultink, Rainer Gross and Joseph G.A.J. Hautvast. 2002. Nutritional Status and Linear Growth of Growth of Indonesian Infants in West Java are Determined More By Prenatal Environment than by Postnatal Factors. $J$ Nutr. 2002. 132: 2202-2207.

Shrimpton, Victoria C.G, deOnis M, Lima R.C, Blossner M, Clugston G. Worldwide Timing of Growth Faltering: Implications for Nutritional Interventions. Pediatrics 2001; 107: e75.

Shrimpton, Victoria C.G, deOnis M, Lima R.C, Blossner M, Clugston G. 2002. Worldwide Timing of Growth Faltering: Implications for Nutritional Interventions. Pediatrics 2002; 107: e75.

Sulastri delmi, 2012. Faktor Determinan Kejadian Stunting pada Anak Usia Sekolah di Kecamatan Lubuk Kilangan Kota Padang. Majalah Kedokteran Andalas, No.1. Vol.36. Januari-Juni 2012.

Supariasa I.D.N, Bakri B, Fajar I. 2002. Penilaian Status Gizi. Jakarta: Penerbit Buku Kedokteran EGC.

Susilowati, Kusharisupeni, Fikawati S, Achmad
K. 2010. Breast Feeding Duration and Children's Nutritional Status at Age 12-24 Months. Paediatrica Indonesiana. 2010; 50(1): 56-61.

Shrimpton, Roger, Cesar G.Victora, Mercedes de Onis, Rosangela Costa Lima, Monika Blossner, and Graeme Clugston. 2001. Worldwide Timing of Growth Faltering: Implications for Nutritional Interventions. Pediatritcs;107(5).

Shrimpton, Roger. 2002. Growth Monitoring in The Life Cycle. In: International Seminar on Child Growth and Poverty, Jakarta Indonesia, 10-13 November 2002.

Taguri A.E, Ibrahim B, Salah M.M, Abdel M.A, Oliver G, Pilar G, Serge H. 2008. Risk factors for stunting among under-fives in Libya. Public Health Nutrition. 2008 Sept 15: 12(8). 1411-1149.

Terati, Sartono, Yunita Nazarena. 2013. Studi Determinan Kejadian Stunted pada Anak Balita Pengunjung Posyandu Wilayah Kerja Dinkes kota Palembang Tahun 2013. Poltekkes Palembang

UNICEF. 2013. The State of the World's Children. Oxford. Univ. Press

Walker W.A, Watkins J.B, Duggan C. 2003. Nutrition in Pediatric. London: BC Decker Inc.

World Health Organization. 2006. Breastfeeding in The WHO Mulcentre Growth Reference Study. Acta Padiatrica.

World Health Organization. 2008. Child Growth Standars. Methods and Development. Geneva.

Yupi Supartini. 2004. Buku Ajar Konsep Dasar Keperawatan Anak. Jakarta: EGC. 